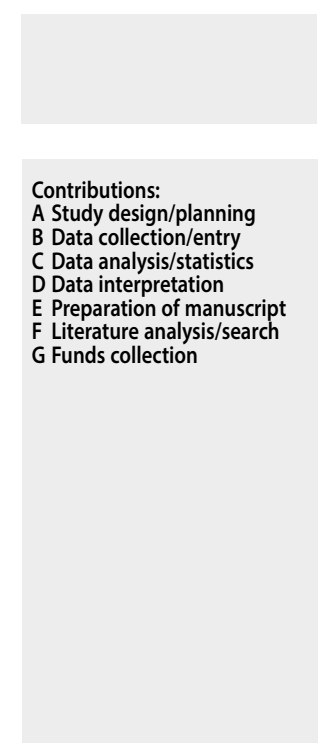

\title{
EFFICIENCY OF DISTORTION PRODUCT OTOACOUSTIC EMISSIONS AS A METHOD FOR OTOTOXICITY MONITORING
}

\author{
Gayane Sargsyan 1,2,A,C-E, Vigen Bakhshinyan ${ }^{3, D}$, Armen Nazanyan ${ }^{4, B}$, \\ Ani Vardanyan ${ }^{1, F}$, Naira Hovhannesyan ${ }^{5, B}$, Levon Badalyan ${ }^{5, B}$, \\ Gnel Ananyan ${ }^{2, E}$, Arthur Shukuryan ${ }^{6, E, G}$ \\ ${ }^{1}$ ENT Department, YSMU, Armenia \\ ${ }^{2}$ ENT Department, YSMU, Nairi MC, Armenia \\ ${ }^{3}$ CI Centre, National Research for Audiology and Hearing Rehabilitation, Russia \\ ${ }^{4}$ ENT Department, Erebouni MC, Armenia \\ ${ }^{5}$ Department of Chemotherapy, Nairi MC, Armenia \\ ${ }^{6}$ ENT Department, YSMU, Erebouni MC, Armenia
}

Corresponding author: Gayane Sargsyan; ENT Department, YSMU, Koryun 2, 0025, Yerevan, Armenia; email: gajane.sargsian@yahoo.de; Phone: +37499422801

\begin{abstract}
Objective: The purpose of this study is to describe hearing and auditory functional changes in patients receiving platinum-based treatments and to estimate the capacity of DPOAE and pure tone audiometry in evaluating ototoxicity as well as evaluating the risk factors of ototoxicity. Design: Standard pure tone audiometry at frequencies of $250-8000 \mathrm{~Hz}$, and also at $12000 \mathrm{~Hz}$ and DPOAE recording were tested prior to starting chemotherapy and once again at the end of our program.

Study sample: 56 patients receiving cisplatin and carboplatin were tested.

Results: At the conventional frequencies, ototoxicity occurred in 6 (33\%) of 18 patients who received cisplatin and in 12 (32\%) of 38 carboplatin patients. Ototoxic hearing loss only at $12000 \mathrm{~Hz}$ occurred in $5(28 \%)$ patients who received cisplatin and in $2(5 \%)$ carboplatin patients. DPOAEs declined in $9(75 \%)$ of 12 patients who received cisplatin and in 7 (44\%) of 16 carboplatin patients. Increased dosage of platinum brought about hearing loss. Our study also investigated the initial hearing threshold as a risk factor for ototoxicity development.
\end{abstract}

Conclusion: Ototoxicity monitoring ought to be an important and valuable option in patients being treated with chemotherapy.

Key words: platinum ototoxicity $\bullet$ hearing loss $\bullet$ DPOAE $\bullet$ PTA $\bullet$ cumulative dose

\section{EFEKTYWNOŚĆ EMISJI PRODUKTÓW ZNIEKSZTAŁCEŃ W MONITOROWANIU OTOTOKSYCZNOŚCI}

\begin{abstract}
Streszczenie
Cel: Celem niniejszego badania jest opisanie zmian funkcjonalnych słuchu u pacjentów, u których zastosowano leczenie na bazie platyny oraz oszacowanie efektywności emisji produktów zniekształceń (DPOAE) i audiometrii tonalnej w ocenie ototoksyczności, a także analiza czynników ryzyka ototoksyczności.

Projekt: Przeprowadzono standardowe badania audiometrii tonalnej przy częstotliwościach $250-8000 \mathrm{~Hz}$ oraz $12000 \mathrm{~Hz}$ oraz badanie DPOAE przed rozpoczęciem chemioterapii i ponownie po zakończeniu programu.

Próba badanych: Badania przeprowadzono u 56 pacjentów otrzymujących cisplatynę i karboplatynę.

Wyniki: Ototoksyczność na poziomie konwencjonalnych częstości wystapiła u 6 (33\%) z 18 pacjentów otrzymujących cisplatynę i u 12 (32\%) z 38 pacjentów otrzymujących karboplatynę. Ototoksyczny ubytek słuchu tylko przy częstotliwości $12000 \mathrm{~Hz}$ wystąpił u 5 (28\%) pacjentów otrzymujących cisplatynę i $2(5 \%)$ pacjentów otrzymujących karboplatynę. DPOAE pogorszyły się u $9(75 \%)$ z 12 pacjentów otrzymujących cisplatynę i u 7 (44\%) z 16 pacjentów otrzymujących karboplatynę. Zwiększona dawka platyny spowodowała utratę słuchu. W niniejszym badaniu analizowano również początkowy próg słyszenia jako czynnik ryzyka rozwoju ototoksyczności.
\end{abstract}

Wnioski: Monitorowanie ototoksyczności powinno być istotną i wartościową opcją możliwą do wykorzystania u pacjentów leczonych chemioterapią. Słowa kluczowe: ototoksyczność platyny • niedosłuch $\bullet$ DPOAE $\bullet$ PTA • dawka skumulowana

\section{Introduction}

Platinum-based antineoplastic drugs are widely used for the treatment of numerous malignant tumors. Cisplatin, which is a first-generation platinum-based antineoplastic, has widespread use in both children and adults, and has unrivaled efficacy in the treatment of certain tumors [1]. Alas, it is considered as one of the most ototoxic antineoplastic 
agents [2]. Cisplatin is more ototoxic than carboplatin, even though when administered in high doses, carboplatin is as equally ototoxic [3]. Severity of platinum-based antineoplastic drugs is dependent upon the cumulative dose administered and is very individual $[4,5]$. Hence, ototoxicity must be monitored in every patient.

Standard pure-tone audiometry is the gold standard for diagnosing hearing loss. Extended high frequency (EHF) audiometry and otoacoustic emission (OAE) tests are considered to be more sensitive for detecting ototoxic injuries [6,7]. According to refs [6] and [7], these two methods can record changes in the auditory system long before ototoxicity affects the range of fundamental speech frequencies.

EHF audiometry uses pure-tone audiometry to assess hearing thresholds at frequencies above $8 \mathrm{kHz}$. Hearing loss usually starts at the highest audible frequencies, and so platinum-based ototoxicity exhibits effects on the sensory cells of the base of the cochlea $[8,9]$ where high frequency sounds are processed.

OAE performs an objective evaluation of the function of the outer hair cells of the cochlea. The outer hair cells are the first structures of the inner ear to be impaired by platinum [10]. Hence, changes in OAE outcomes can reflect cochlear pathologies pertaining to hearing loss that are yet to be clinically visible if chemotherapy is to continue. Changes in outer hair cells are disclosed by distortion product OAE (DPOAE) amplitude decline, dynamic narrowing of response spectrum, and/or complete loss of response due to outer hair cell damage [11]. Changes in DPOAEs due to cisplatin are expressed in both children and adults $[12,13,9]$.

To predict if a patient has ototoxic hearing loss or not is only achieved by direct evaluation of hearing function. Even though the risk of developement of hearing loss by ototoxic agents depends on the dose, time span, and frequency of administration, almost all cases vary individually [5].

\section{Aim}

The aim of this study is to describe hearing and auditory functional changes in patients receiving platinum-based treatments and to estimate the capacity of DPOAE and pure tone audiometry to gauge ototoxicity, as well as to evaluate risk factors for ototoxicity.

\section{Materials and methods}

For the first time in Armenia, a program for monitoring ototoxicity in patients receiving platinum-based chemotherapy was implemented in Nairi MC between the period October 2018 to March 2020. This program was realized and funded by the Science Committee of the Ministry of Education and Science of Armenia. The study included 56 patients whose data are presented in Table 1.

Investigation of patients was carried out as follows:

Standard pure tone audiometry with frequencies of 250$8000 \mathrm{~Hz}$. Since our audiometer allowed us, we were able to test patients at $12000 \mathrm{~Hz}$ as well. All patients were tested 48-24 hours prior to beginning chemotherapy and once again at the end of our program, regardless of whether they finished the treatment course or not.

Baseline hearing impairment was evaluated and classified according to the International Bureau for Audiology: normal hearing (mean hearing threshold $<20 \mathrm{~dB}$ at various frequencies of 500, 1000, 2000, and $4000 \mathrm{~Hz}$ ), mild hearing loss (mean threshold of 21-40 dB), moderate hearing loss (mean threshold of $41-70 \mathrm{~dB}$ ). There were no patients with more profound hearing loss [14].

DPOAE recordings were performed at the same timings as audiometry. DPOAE was recorded at the $2 \mathrm{f} 1-\mathrm{f} 2$ frequency as a DP-gram, with $\mathrm{L} 1=65 \mathrm{~dB}$ sound pressure level (SPL), $\mathrm{L} 2=55 \mathrm{~dB}$ SPL, and $\mathrm{f} 2 / \mathrm{f} 1=1.22$. DPOAE studies were performed only on patients with baseline normal hearing, normal to mild, or mild hearing loss, based on their PTA results. Patients with more advanced hearing loss were excluded from DPOAE study.

Evaluation of ototoxicity according to pure tone audiometry results was realized as follows:

(a) $\geq 20 \mathrm{~dB}$ change at any one test frequency;

(b) $\geq 10 \mathrm{~dB}$ change at any two consecutive test frequencies; or

(c) loss of response at three consecutive test frequencies at which responses were previously obtained [15].

In the case of changes between initial and final results, they were considered an outcome of ototoxicity if the results of investigations exhibited almost the same margin of change when performed a second time. To evaluate the ototoxic effect in each case the final results were compared with the initial ones.

Evaluation of ototoxicity according to DPOAE results was determined by accepting a change of $7 \mathrm{~dB}$ or more in DPOAE amplitude decline, since there are no specific standards for this method to determine ototoxicity $[16,9]$. Those

Table 1. Characteristics of platin subjects

\begin{tabular}{ccc}
\hline & Patients treated with cisplatin & Patients treated with carboplatin \\
\hline Total number of patients & 18 & 38 \\
\hline Sex & $\begin{array}{c}\text { Male } 10 \\
\text { Female } 8\end{array}$ & Female 28 \\
\hline Age (mean, range) & $60.3(36-76)$ & $52.9(38-66)$ \\
\hline Total number of doses (mean, range) & $3.7(1-8)$ & $3.8(1-8)$ \\
\hline Final cumulative drug dose, mg (mean, range) & $406(50-1200)$ & $2561(500-5400)$ \\
\hline
\end{tabular}


changes were considered to be a result of ototoxicity if the test was performed again after the program ended and the decline in amplitude was of the same value.

Ototoxicity was also evaluated according to the cumulative dose and the initial threshold of hearing.

Statistical analysis was carried out using GraphPad Prism 8. Descriptive statistics (mean with standard deviation) summarized baseline characteristics, audiological values of hearing, and cumulative doses of therapy of the patients. Paired $t$-tests were used to assess the comparative pre- and post-exposure audiological differences. Unpaired $t$-tests were used to compare mean results of cumulative doses and hearing thresholds across patients who had hearing change with patients who did not have changes in hearing thresholds after exposure. $P$-values less than 0.05 were considered statistically significant. All reported $P$-values were from two-tailed tests.

\section{Results}

At baseline, 9 patients receiving cisplatin had normal hearing sensitivity at conventional audiological frequencies, 2 had normal to mild hearing loss, 1 had mild hearing loss, 5 had mild to moderate hearing loss, and 1 patient had moderate hearing loss.

Prior to chemotherapy, 11 patients receiving carboplatin had normal hearing, 3 had normal to mild hearing loss, 4 had mild hearing loss, 15 had mild to moderate hearing loss, while 5 had moderate hearing loss. In patients receiving carboplatin, measurable DPOAEs were recorded in 16 of them, who had normal $(n=11)$, normal to mild $(n=3)$, and mild $(n=2)$ hearing loss at baseline. Two patients, who received carboplatin, with mild hearing loss at baseline, were also excluded from this analysis as they did not have measurable DPOAEs to begin with. There were 12 patients receiving cisplatin who had measurable DPOAEs and who also had normal $(n=9)$, normal to mild $(n=2)$, and mild hearing loss $(n=1)$ at baseline.

The mean thresholds of patients receiving cisplatin and carboplatin, at baseline and after treatment, are shown in Figure 1 and Table 2. Statistical analysis using paired $t$-tests showed that a significant difference between results at baseline and after the treatment were recorded starting from $4 \mathrm{kHz}$, in both medication groups. Of course, these results are debatable, given that ototoxicity coincides with some hearing loss [14]. Based on these standards, bilateral ototoxicity occurred in 5 (28\%) of 18 patients who received cisplatin. Only $1(6 \%)$ patient had ototoxicity conditioned unilateral hearing loss. No hearing loss at the conventional frequencies was noted in $5(28 \%)$ patients, but there was the presence of ototoxic hearing loss at $12 \mathrm{kHz}$. All patients who had hearing loss at conventional frequencies also had hearing loss at $12 \mathrm{kHz}$. There were 10 patients receiving carboplatin $(26 \%)$ who exhibited bilateral hearing loss at conventional frequencies, while 2 (5\%) patients exhibited unilateral hearing loss. Both these patient groups exhibited ototoxic

Table 2. Mean thresholds (with SD) at baseline and post-treatment with carboplatin ( $n=38$ patients, 76 ears) and cisplatin ( $n=18$ patients, 36 ears) at conventional frequencies and at $12000 \mathrm{~Hz}$

\begin{tabular}{|c|c|c|c|c|c|c|c|}
\hline \multicolumn{8}{|c|}{ Patients treated with cisplatin } \\
\hline & $500 \mathrm{~Hz}$ & $1000 \mathrm{~Hz}$ & $2000 \mathrm{~Hz}$ & $4000 \mathrm{~Hz}$ & $6000 \mathrm{~Hz}$ & $8000 \mathrm{~Hz}$ & $12000 \mathrm{~Hz}$ \\
\hline Baseline hearing, $\mathrm{dB}$ (mean $\pm \mathrm{SD}$ ) & $18.3 \pm 6.2$ & $19.7 \pm 6.7$ & $22.8 \pm 7.3$ & $25.6 \pm 11.1$ & $29.7 \pm 14.7$ & $33.9 \pm 19.7$ & $50.3 \pm 21.5$ \\
\hline Postexposure hearing, $\mathrm{dB}$ (mean $\pm \mathrm{SD}$ ) & $19.7 \pm 6.1$ & $21.7 \pm 7.5$ & $24.4 \pm 8.4$ & $29.7 \pm 12.3$ & $35.8 \pm 17.6$ & $41.9 \pm 20.5$ & $67.5 \pm 23.8$ \\
\hline$p$ & 0.06 & 0.06 & 0.08 & 0.02 & 0.01 & 0.003 & $<0.0001$ \\
\hline \multicolumn{8}{|c|}{ Patients treated with carboplatin } \\
\hline Baseline hearing, $\mathrm{dB}$ (mean $\pm \mathrm{SD})$ & $22.4 \pm 7.1$ & $22.5 \pm 7.1$ & $25.9 \pm 8.7$ & $27.1 \pm 8.2$ & $32.5 \pm 12.3$ & $42.1 \pm 17.6$ & $59.6 \pm 20.9$ \\
\hline Postexposure hearing, $\mathrm{dB}$ (mean $\pm \mathrm{SD}$ ) & $22.1 \pm 7.6$ & $22.1 \pm 7.2$ & $25.9 \pm 8.8$ & $29.1 \pm 9.4$ & $36.9 \pm 13.5$ & $46.1 \pm 17.1$ & $68.9 \pm 21.9$ \\
\hline$p$ & 0.49 & 0.18 & $>0.999$ & 0.03 & 0.01 & 0.0015 & $<0.0001$ \\
\hline
\end{tabular}
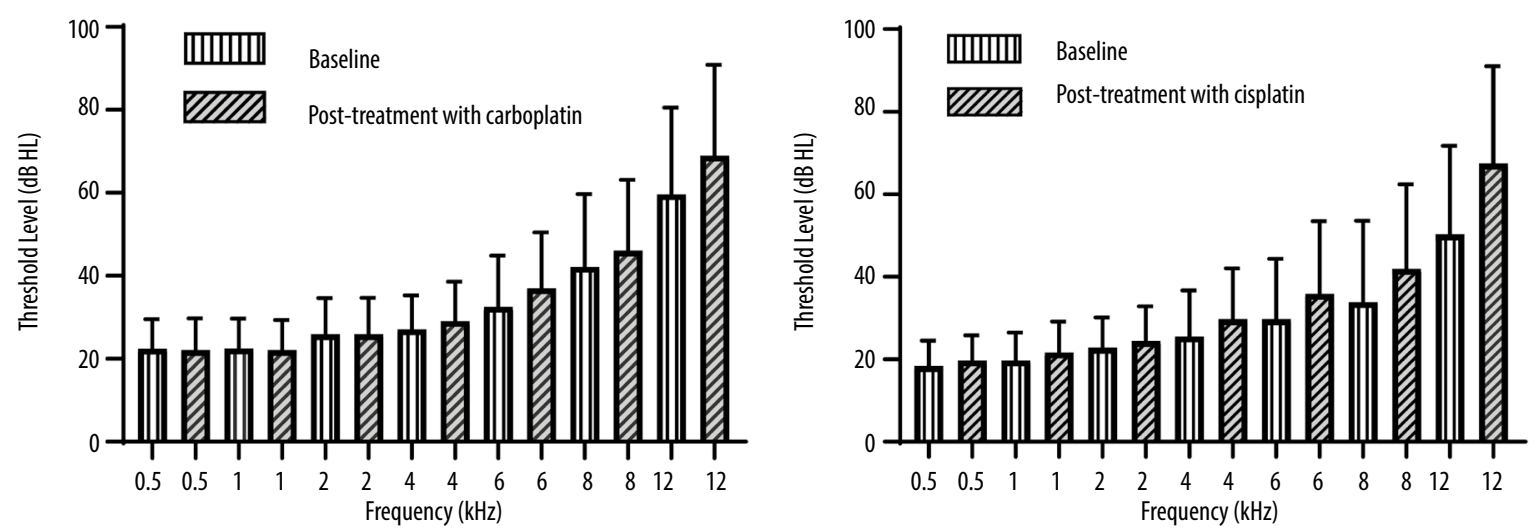

Figure 1. Left: Group mean thresholds (with SD) at baseline and post-treatment with carboplatin ( $n=38$ patients, 76 ears). Right: same for cisplatin ( $n=18$ patients, 36 ears). Conventional frequencies plus $12 \mathrm{kHz}$ 
Table 3. Mean (with SD) of distortion product otoacoustic emission (DPOAE) and noise floor amplitudes at baseline and after treatment with carboplatin for 16 patients ( 32 ears) and with cisplatin for 12 patients ( 24 ears)

\begin{tabular}{|c|c|c|c|c|c|}
\hline \multicolumn{6}{|c|}{ Patients treated with cisplatin } \\
\hline & $1000 \mathrm{~Hz}$ & $2000 \mathrm{~Hz}$ & $4000 \mathrm{~Hz}$ & $6000 \mathrm{~Hz}$ & $8000 \mathrm{~Hz}$ \\
\hline Baseline amplitude of DPOAE, $\mathrm{dB}($ mean $\pm \mathrm{SD})$ & $10.8 \pm 2.3$ & $10.5 \pm 2.3$ & $9.8 \pm 1.9$ & $9.5 \pm 2.1$ & $8.9 \pm 1.7$ \\
\hline Postexposure amplitude of DPOAE, $\mathrm{dB}$ (mean $\pm \mathrm{SD}$ ) & $10.4 \pm 2.5$ & $8.6 \pm 2.1$ & $3.1 \pm 4.5$ & $-0.8 \pm 7.4$ & $-3.2 \pm 7.9$ \\
\hline$p$ & 0.05 & $<0.0001$ & $<0.0001$ & $<0.0001$ & $<0.0001$ \\
\hline Baseline amplitude of noise floor, $\mathrm{dB}$ (mean $\pm \mathrm{SD}$ ) & $-2.1 \pm 1.4$ & $-5.3 \pm 1.4$ & $-10.6 \pm 2.5$ & $-12.2 \pm 1.8$ & $-14.7 \pm 2.5$ \\
\hline Postexposure amplitude of noise floor, $\mathrm{dB}$ (mean $\pm \mathrm{SD}$ ) & $-2.2 \pm 1.5$ & $-5.3 \pm 1.3$ & $-10.7 \pm 2.6$ & $-12.5 \pm 1.9$ & $-13.7 \pm 1.5$ \\
\hline$p$ & 0.90 & 0.92 & 0.82 & 0.39 & 0.24 \\
\hline \multicolumn{6}{|c|}{ Patients treated with carboplatin } \\
\hline Baseline amplitude of DPOAE, dB (mean \pm SD) & $11.1 \pm 2.0$ & $10.4 \pm 1.6$ & $9.9 \pm 1.3$ & $9.4 \pm 1.7$ & $8.7 \pm 1.7$ \\
\hline Postexposure amplitude of DPOAE, $\mathrm{dB}($ mean $\pm \mathrm{SD})$ & $10.8 \pm 1.8$ & $9.0 \pm 1.7$ & $4.8 \pm 3.9$ & $0.9 \pm 7.4$ & $-1.2 \pm 7.7$ \\
\hline$p$ & 0.05 & $<0.0001$ & $<0.0001$ & $<0.0001$ & $<0.0001$ \\
\hline Baseline amplitude of noise floor, $\mathrm{dB}$ (mean $\pm \mathrm{SD}$ ) & $-1.9 \pm 1.2$ & $-4.8 \pm 1.0$ & $-8.5 \pm 3.3$ & $-11.2 \pm 1.7$ & $-13.2 \pm 2.0$ \\
\hline Postexposure amplitude of noise floor, $\mathrm{dB}($ mean $\pm \mathrm{SD}$ ) & $-2.1 \pm 1.4$ & $-4.0 \pm 1.5$ & $-9.1 \pm 3.3$ & $-11.6 \pm 1.4$ & $-12.8 \pm 1.3$ \\
\hline$p$ & 0.63 & 0.07 & 0.14 & 0.38 & 0.14 \\
\hline
\end{tabular}

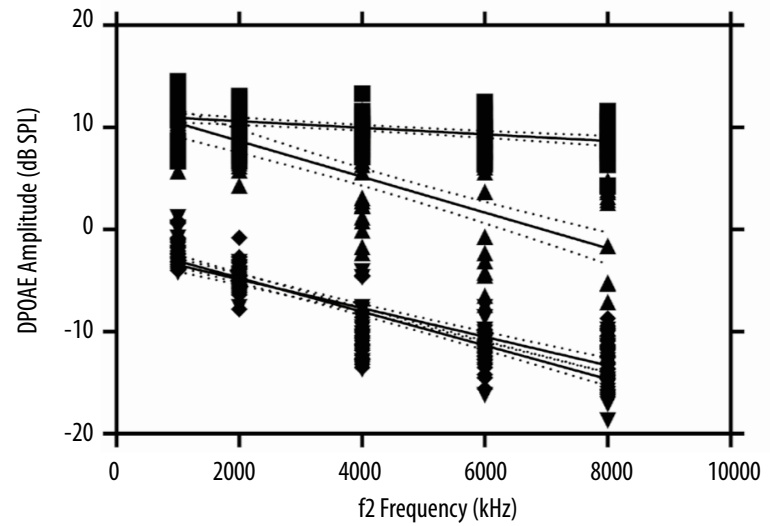

- Baseline
+ Post-treatment with carboplatin
$\rightarrow$ Baseline noise floor
$\rightarrow$ Post-treatment noise floor

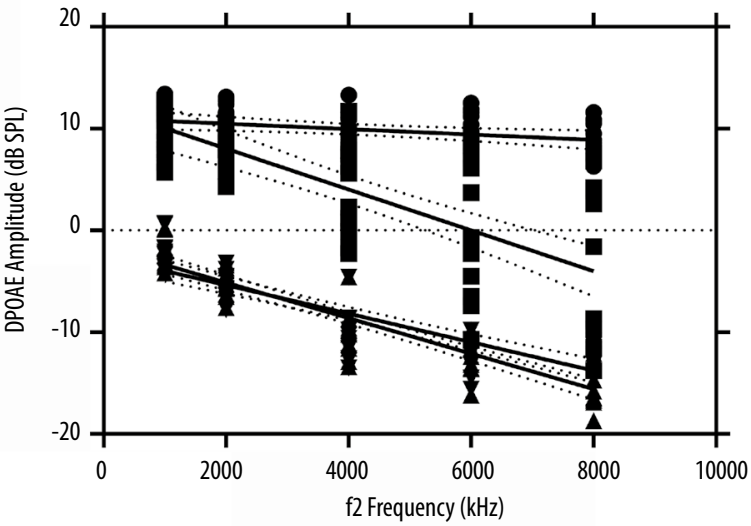

- Baseline
- Post-treatment with cisplatin
× Baseline noise floor
$\mp$ Post-treatment noise floor

Figure 2. Left: Means (with SD) of distortion product otoacoustic emission (DPOAE) amplitude as a function of $\mathrm{f} 2$ frequency at baseline and after treatment with carboplatin for 16 patients (32 ears). Right: same for cisplatin for 12 patients ( 24 ears)

hearing loss at $12 \mathrm{kHz}$ as well. From the carboplatin receiving patients, 2 (5\%) didn't have hearing loss at conventional frequencies but displayed ototoxic hearing loss at $12 \mathrm{kHz}$.

Figure 2 and Table 3 show the group mean DPOAEs at baseline and at completion of treatment with cisplatin and carboplatin. Statistical analysis using paired $t$-tests showed a significant difference between results at baseline and after treatment, starting from $2000 \mathrm{~Hz}$, in both medication groups. This is again debatable, given that ototoxicity in this study was determined by accepting a decline of $7 \mathrm{~dB}$ or more in DPOAE amplitude. Based on these standards, DPOAEs declined bilaterally in $9(75 \%)$ out of 12 patients who received cisplatin. Ototoxic changes in DPOAE where recorded in all patients who exhibited hearing loss in standard pure tone audiometry. DPOAEs of 4 patients recorded a bilateral decline in amplitude without them developing ototoxic hearing loss in standard pure tone audiometry, although they did so at $12 \mathrm{kHz}$.

DPOAEs declined in 7 (44\%) of 16 patients who received carboplatin. Those changes were recorded in all patients who developed hearing loss in standard pure tone audiometry. There were 2 patients who developed ototoxic hearing loss at $12 \mathrm{kHz}$ only; one of them did not register a tangible decline in amplitude which can be considered as an 
Table 4. Hearing changes conditioned by cisplatin cumulative dosage and initial hearing threshold

\begin{tabular}{|c|c|c|c|}
\hline & $\begin{array}{c}\text { No hearing change at } \\
\text { conventional frequencies } \\
(250-8000 \mathrm{~Hz})\end{array}$ & $\begin{array}{c}\text { Hearing change at } \\
\text { conventional frequencies } \\
(250-8000 \mathrm{~Hz})\end{array}$ & $\begin{array}{l}\text { Hearing change only at } \\
12000 \mathrm{~Hz}\end{array}$ \\
\hline Number of patients & 7 & 6 & 5 \\
\hline $\begin{array}{l}\text { Cumulative dose, mg (mean } \\
\pm \mathrm{SD} \text { ) }\end{array}$ & $\begin{array}{c}154.3 \pm 86.4 \\
(\min 50, \max 300)\end{array}$ & $\begin{array}{c}688.3 \pm 298.4 \\
(\min 450, \max 1200) \\
p=0.0008\end{array}$ & $\begin{array}{c}418.0 \pm 113.7 \\
(\min 300, \max 600) \\
p=0.001\end{array}$ \\
\hline $\begin{array}{l}\text { Baseline hearing, } \mathrm{dB} \text { (mean } \\
\pm \mathrm{SD} \text { ) }\end{array}$ & $\begin{array}{c}36.4 \pm 18.1 \\
(\min 15, \max 80)\end{array}$ & $\begin{array}{c}23.9 \pm 11.2 \\
(\min 10, \max 50) \\
p=0.015\end{array}$ & $\begin{array}{c}27.3 \pm 13.6 \\
(\min 15, \max 55) \\
p=0.11\end{array}$ \\
\hline
\end{tabular}

Table 5. Hearing changes conditioned by carboplatin cumulative dosage and initial hearing threshold

\begin{tabular}{lcc}
\hline & $\begin{array}{c}\text { No hearing change at conventional } \\
\text { frequencies }(\mathbf{2 5 0 - 8 0 0 0 ~ H z )}\end{array}$ & $\begin{array}{c}\text { Hearing change at conventional } \\
\text { frequencies }(\mathbf{2 5 0 - 8 0 0 0 ~} \mathbf{~ z})\end{array}$ \\
\hline Number of patients & 24 & 12 \\
\hline Cumulative dose, $\mathrm{mg}($ mean $\pm \mathrm{SD})$ & $1718 \pm 893(\min 280, \max 3000)$ & $4373 \pm 692(\min 3600, \max 5400) p<0.0001$ \\
\hline Baseline hearing, $\mathrm{dB}($ mean $\pm \mathrm{SD})$ & $35.8 \pm 14.8(\min 10, \max 65)$ & $30.1 \pm 13.7(\min 10, \max 60) p=0.06$ \\
\hline
\end{tabular}

Table 6. DPOAE amplitude ototoxicity changes conditioned by cumulative dosage

\begin{tabular}{|c|c|c|c|}
\hline & No change in the amplitude of DPOAE & Change in the amplitude of DPOAE & $\boldsymbol{p}$ \\
\hline \multicolumn{4}{|c|}{ Patients treated with cisplatin } \\
\hline Number of patients & 3 & 9 & \\
\hline $\begin{array}{l}\text { Cumulative dose, } \mathrm{mg} \\
\text { (mean } \pm \text { SD) }\end{array}$ & $\begin{array}{c}230 \pm 76 \\
(\min 150, \max 300)\end{array}$ & $\begin{array}{c}518 \pm 170 \\
(\min 300, \max 900)\end{array}$ & 0.02 \\
\hline \multicolumn{4}{|c|}{ Patients treated with carboplatin } \\
\hline Number of patients & 9 & 7 & \\
\hline $\begin{array}{l}\text { Cumulative dose, mg } \\
\text { (mean } \pm \text { SD) }\end{array}$ & $\begin{array}{c}1766 \pm 805 \\
(\min 520, \max 2700)\end{array}$ & $\begin{array}{c}4411 \pm 745 \\
(\min 3600, \max 5400)\end{array}$ & $<0.0001$ \\
\hline
\end{tabular}

outcome of ototoxicity, while the other did not have a measurable DPOAE from the beginning.

Tables 4 and 5 show the dependency of changes in hearing thresholds at standard frequencies on the cumulative drug dose and initial hearing threshold. For carboplatin, data has not been obtained from patients who only exhibited hearing loss at $12 \mathrm{kHz}$ because of very small sample size. Increasing dosage brings about hearing loss. Those patients who did not develop hearing loss after treatment had a cisplatin cumulative dosage of $154 \pm 86 \mathrm{mg}$, and a carboplatin cumulative dosage of $1718 \pm 893 \mathrm{mg}$. On the other hand, those patients who developed hearing loss at standard frequencies post treatment had a cisplatin cumulative dose of $688 \pm 298 \mathrm{mg}$ and a carboplatin cumulative dose of $4373 \pm 692 \mathrm{mg}$, while those who had hearing loss at $12 \mathrm{kHz}$ had a cumulative cisplatin dosage of $418 \pm 114 \mathrm{mg}$. In the case of both of these treatments, comparison of dosages showed that patients receiving platinum-based chemotherapy with and without changes in hearing exhibited a significant difference between cumulative drug doses $(p<0.05)$. Particularly with cisplatin, this was evident even when dosage data were compared from patients who had only changes at $12 \mathrm{kHz}$ and those without changes in hearing.
There are also the predicted hearing changes that are based on initial hearing thresholds. The same patients' initial hearing thresholds were compared and alterations were recorded. Those alterations were significant in patients treated with cisplatin $(p<0.05)$ while not so much in patients treated with carboplatin $(p>0.05)$, the only exception being a patient who was treated with cisplatin who only had changes at $12 \mathrm{kHz}$. The effect of cumulative dosage on DPOAE level was as follows: cumulative dosage with changes in DPOAE amplitude for cisplatin was $518 \pm 170 \mathrm{mg}$, for carboplatin it was $4411 \pm 745$. Cumulative dosage without changes in DPOAE for cisplatin was $230 \pm 76 \mathrm{mg}$, and for carboplatin it was $1766 \pm 805 \mathrm{mg}$.

Thus, in both these treatments, comparison of dosages showed that patients receiving platinum-based chemotherapy (with and without changes in DPOAE amplitude) exhibited a significant difference between cumulative drug doses $(p<0.05)$ (Table 6).

The patients treated with cisplatin who did not have a hearing loss post-treatment had an initial hearing threshold of up to $36.4 \pm 18.1 \mathrm{~dB}$. Those patients who had a hearing loss at $12 \mathrm{kHz}$ had an initial hearing threshold of $27.3 \pm 13.6 \mathrm{~dB}$, while those patients who had hearing loss at 
standard frequencies as well had an initial hearing threshold of $23.9 \pm 11.2 \mathrm{~dB}$. Those patients treated with carboplatin who did not have a hearing loss post-treatment had an initial hearing threshold of up to $35.8 \pm 14.8 \mathrm{~dB}$, while those who had hearing changes at standard frequencies had an initial hearing threshold of $30.1 \pm 13.7 \mathrm{~dB}$.

\section{Discussion}

Since platinum-based antineoplastic drugs are considered the best evidence-based treatment for certain tumors, some patients may develop ototoxic hearing loss. Ototoxicity monitoring allows the development of hearing loss in case of chemotherapy to be monitored, which in turn helps prevent advancement of this disabling condition.

Hearing and auditory functional changes have been studied in 56 adults who were treated with cisplatin or carboplatin. All patients underwent standard pre-treatment pure tone audiometry and at $12 \mathrm{kHz}$. These tests were repeated at the end of the program. Only 28 patients who had undergone DPOAE analysis had pre-treatment measurable DPOAEs. The exclusion criterion for this method was moderate or mild to moderate hearing loss at baseline, as per PTA results. All patients who recorded hearing changes at standard frequencies definitely had hearing loss at $12 \mathrm{kHz}$ as well. There were also ototoxic DPOAE changes in case of an initial measurable DPOAE.

Because of the lack of possibility to perform EHF audiometry, we were only able to record thresholds at $12 \mathrm{kHz}$. Even so, our results from the recorded thresholds were able to confirm that EHF audiometry is an invaluable tool for monitoring ototoxicity $[9,6]$. The downsides of this method are that it requires the patient to fully concentrate while performing the test and it is time consuming, since it is usual for patients not to be able to conform to these situations right after finishing a course of chemotherapy. In contrast, DPOAE testing takes less time and does not require the patient's active participation. According to our results, DPOAE as an ototoxicity monitoring tool is more effective than standard pure tone audiometry and is most probably equal in efficiency to EHF audiometry. Nonetheless, DPOAE also has its downsides, as it cannot produce readings in case of middle ear pathology. It is also common for a patient to have a baseline hearing loss and hence the DPOAE amplitude is small from the beginning. This is why only $50 \%$ of our patients were tested using this method. Besides, the criteria for ototoxic changes in DPOAEs have not been determined. All in all, the value of this method is clear. This is shown by our results which have documented that even when hearing loss is not registered at standard frequencies, ototoxic changes in DPOAE amplitudes are present.

It would be desirable to perform a follow-up study to observe which of the aforementioned methods can detect auditory functional ototoxic changes earlier. Our study did not investigate this point, considering only the initial and terminal results.

Our study also investigated the initial hearing threshold as a risk factor for ototoxicity development. We compared the initial hearing thresholds of patients who had hearing changes with those who did not have hearing changes after treatment. Those who had hearing changes after treatment initially had better hearing than those who did not have a decrease in hearing after treatment. This observation was more pronounced in patients who received cisplatin as chemotherapy rather than those who received carboplatin. Outcomes exhibiting significant changes were recorded by Reavis et al. (2011), with their study using a 'sensitive range for ototoxicity' (SRO) monitoring [1]. Reavis et al. (2008) found that changes in hearing thresholds were not present in patients who initially had varying hearing levels [17]. Studies arguing the opposite exist as well: the worse the initial hearing thresholds are, the more susceptible to ototoxic effects these individuals are $[18,19]$.

Based on the correlation mentioned above, we did not study the effect of the patients' age on hearing loss. Given that our results showed that there is correlation between baseline hearing and ototoxic hearing loss, and that older patients had baseline impaired hearing, we could not objectively estimate an age effect on hearing loss. We have noted in this study that the ultimate cumulative dose of cisplatin was $405 \mathrm{mg}$ while that of carboplatin was $2560 \mathrm{mg}$. One expects that an increase of platinum dose should give rise to hearing loss. According to our results, the comparison of cumulative doses between patients with and without hearing changes was significant. Patients receiving a mean of $154 \mathrm{mg}$ cisplatin did not register hearing loss, whereas patients receiving a mean of $418 \mathrm{mg}$ registered a hearing loss only at $12 \mathrm{kHz}$, and those receiving $688 \mathrm{mg}$ registered a hearing loss at standard frequencies as well. Almost the same data were recorded by Reavis et al. [1]. Hearing loss developed in those receiving a mean of $425 \mathrm{mg}$ cisplatin, while those receiving a mean of $250 \mathrm{mg}$ cisplatin did not develop hearing loss. But they noted that pre-exposure hearing was an effect modifier of the cisplatin dose-hearing change relationship. Schaefer et al. [20] noted that patients receiving $400 \mathrm{mg}$ and more ended up experiencing hearing loss. Those who were administered a mean of $1718 \mathrm{mg}$ carboplatin did not register hearing loss, while those who were administered a mean of $4373 \mathrm{mg}$ registered hearing loss at standard frequencies. An effect of cumulative dose on DPOAEs was also shown. The comparison of cumulative doses between patients with and without changes in DPOAE was significant. This can be related to both groups, receiving either cisplatin or carboplatin.

The effect of the patient's gender on hearing loss was not evaluated in this study. Some of our patients were receiving platinum-based therapy for treatment of diseases solely related to the female gender, and so we could not objectively estimate the effect of gender on hearing loss.

\section{Conclusion}

Our study confirms that ototoxicity monitoring holds an important and valuable place in patients being treated with chemotherapy. Such investigations should continue and be expanded to include EHF audiometry as well. If a larger sample size were available, we expect it would be possible to devise more accurate ototoxic parameters using DPOAEs. Such efforts would allow one to manage and prevent the origination of disability caused by hearing loss in these patients. 


\section{References}

1. Reavis KM, McMillan G, Austin D, et al. Distortion-product otoacoustic emission test performance for ototoxicity monitoring. Ear Hear, 2011; 32(1): 61-74.

2. Hartmann JT, Lipp HT. Toxicity of platinum compounds. Expert Opin Pharmacother, 2003; 4: 889-901.

3. Macdonald RM, Harrison RV, Wake M, Bliss B, Macdonald RE. Ototoxicity of carboplatin: comparing animal and clinical models at the Hospital for Sick Children. J Otolaryngol, 1994; 23(3): 151-9.

4. Li Y, Womer RB, Silber JH. Predicting cisplatin ototoxicity in children: the influence of age and the cumulative dose. Eur J Cancer, 2004; 40(16): 2445-51.

5. Rademaker-Lakhai JM, Crul M, Zuur L. Relationship between cisplatin administration and the development of ototoxicity. J Clin Oncol, 2006; 24(6): 918-24.

6. Fausti SA, Larson VD, Noffsinger D, Wilson RH, Phillips DS, Fowler CG. High-frequency audiometric monitoring strategies for early detection of ototoxicity. Ear Hear, 1994; 15(3): 232-9.

7. Ress BD, Sridhar KS, Balkany TJ, Waxman GM, Stagner BB, Lonsbury-Martin BL. Effects of cis-platinum chemotherapy on otoacoustic emissions: the development of an objective screening protocol. Otolaryngol Head Neck Surg, 1999; 121(6): 693-701.

8. Wright CG, Schaefer SD. Inner ear histopathology in patients treated with cis-platinum. Laryngoscope, 1982; 92(12): 1408-13.

9. Knight KR, Kraemer DF, Winter C, Neuwelt EA. Early changes in auditory function as a result of platinum chemotherapy: use of extended high-frequency audiometry and evoked distortion product otoacoustic emissions. J Clin Oncol, 2007; 25(10): 1190-95.

10. Rybak LP, Whitworth CA. Ototoxicity: therapeutic opportunities. Drug Discovery Today; 2005; 10: 1313-21.

11. Gorga MP, Neely ST, Bergman B, et al. Otoacoustic emissions from normal-hearing and hearing-impaired subjects: distortion product responses. J Acoust Soc Am, 1993; 93: 2050-60.
12. Stavroulaki P, Apostolopoulos N, Segas J, Tsakanikos M, Adamopoulos G. Evoked otoacoustic emissions: an approach for monitoring cisplatin induced ototoxicity in children. Int J Pediatr Otorhinolaryngol, 2001; 59(1): 47-57.

13. Stavroulaki P, Vossinakis IC, Dinopoulou D, Doudounakis S, Adamopoulos G, Apostolopoulos N. Otoacoustic emissions for monitoring aminoglycoside-induced ototoxicity in children with cystic fibrosis. Arch Otolaryngol Head Neck Surg, 2002; 128(2): $150-155$.

14. BIAP Recommendation 02/1: Audiometric Classification of Hearing Impairments (1996). http://www.biap.org/en/ recommandations/recommendations/tc-02-classification/213rec-02-1-en-audiometric-classification-of-hearing-impairments/ file

15. American Speech-Language-Hearing Association (ASHA).1994. Guidelines for the audiologic management of individuals receiving cochleotoxic drug therapy. 36: 11-19.

16. Beattie RC, Kenworthy OT, Luna CA. Immediate and short-term reliability of distortion-product otoacoustic emissions. Int J Audiol, 2003; 42: 348-54.

17. Reavis KM, Phillips DS, Fausti SA, et al. Factors affecting sensitivity of distortion-product otoacoustic emissions to ototoxic hearing loss. Ear Hear, 2008; 29: 875-93.

18. van der Hulst RJ, Dreschler WA, Urbanus NA. High frequency audiometry in prospective clinical research of ototoxicity due to platinum derivatives. Ann Otol Rhinol Laryngol, 1988; 977(2 Pt 1): 133-7.

19. Bokemeyer C, Berger CC, Hartmann JT, et al. Analysis of risk factors for cisplatin-induced ototoxicity in patients with testicular cancer. Br J Cancer, 1998; 77: 1355-62.

20. Schaefer SD, Post JD, Close LG, Wright CG. Ototoxicity of lowand moderate-dose cisplatin. Cancer, 1985; 56: 1934-9. 